\title{
PHYSICAL AND GEOSPATIAL ATTRIBUTES OF INCEPTISOLS AND ULTISOLS UNDER NATIVE VEGETATION IN HUMAITÁ, AM, BRAZIL
}

\author{
ATRIBUTOS FÍSICOS E GEOESPACIAIS DE CAMBISSOLO E ARGISSOLO DE \\ MATA NATIVA EM HUMAITÁ, AM
}

\author{
Leandro Coutinho ALHO ${ }^{1}$; Milton Cesar Costa CAMPOS $^{2}$; \\ Bruno Campos MANTOVANELLI ${ }^{3}$; Douglas Marcelo Pinheiro SILVA ${ }^{3}$; \\ Zigomar Menezes SOUZA ${ }^{4}$; Jose Mauricio da CUNHA ${ }^{2}$; \\ Marcelo Dayron Rodrigues SOARES ${ }^{2}$
}

1. Professor, Instituto Federal de Educação, Ciência e Tecnologia do Amazonas - IFAM, Lábrea, AM, Brasil. leandro_alho@yahoo.com; 2. Professor, Universidade Federal do Amazonas - UFAM, Humaitá, AM, Brasil; 3. Master student in Soil Science, Universidade Federal Rural de Pernambuco - UFRPE, Recife, PE, Brasil; 4. Professor da FEAGRI, Universidade de Campinas - UNICAMP, Campinas, SP, Brasil.

\begin{abstract}
Natural grasslands with savannah-like characteristics associated to forest mosaics are found within Southern and Eastern Amazonas, Western Rondônia and Northern Roraima, being conditioned to local edaphic factors. The aim of this study was to assess both physical and geospatial attributes of an Cambisol under natural grasslands and an Ultisol under a forest fragment in Humaitá - AM, Brazil. In each area, we established a sampling grid in the dimensions of $70 \times 70 \mathrm{~m}$, with regular sampling spacing of $10 \mathrm{~m}$ and three collection depths: $0.0-0.05,0.05-0.10$ and $0.10-0.20 \mathrm{~m}$, totaling 192 sampling points. Macroporosity (MaP), microporosity (MiP), bulk density (Ds) and total porosity (TP) were determined by soil samples with preserved structure, using a volumetric ring. Soil resistance to penetration (SRP) was measured by an automatic penetrometer after being subjected to a $0.006 \mathrm{MPa}$ tension. Data were submitted to descriptive statistics and geostatistics analysis. The soil under natural grasslands showed values considered critical of Ds, SRP, MaP at

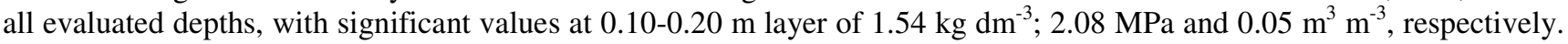
Ultisol under the forest fragments showed higher range values and consequently greater geospatial continuity due to the assessed physical attributes, since this soil has a greater stability of its physical structure. Based on the physical properties of the soil, structural function ineffectiveness of the Ultisol is a key factor for the occurrence of grassland in this region.
\end{abstract}

KEYWORDS: Soils attributes. Natural grasslands. Forest.

\section{INTRODUCTION}

Western Amazon holds 42.97\% of the land within the Legal Amazon area. Overall, it has different physiographies, namely wetlands, dry land, dense forest environments, open forests associated with palm trees and with bamboos, bamboo forests, campinaranas, and various types of natural fields. According to Freitas et al. (2002), in Southern and Eastern Amazonas, Western Rondônia and Northern Roraima, natural fields have savannah traits associated to forest mosaic, which are subjected to local soil factors (CAMPOS et al., 2010).

Notwithstanding phytophysionomic diversity, Campos et al. (2012) highlighted a great variety of interrelated soils within landscape, such as Oxisols under dense forests in plateau areas, Ultisols in forest mosaics, Inceptisols under natural fields (cerrado, with few trees) and Entisols under natural fields (grassy field, with predominance of grasses and sedges). They are interrelated along the landscape, whose high silt content, groundwater upwelling and savannah-like vegetation are striking features of this region.
According to Martins et al. (2006), morphological and hydro-physical soil attributes experience more changes with small variations in terrain, so that the forest soil is deeper and, consequently, has higher volume of water storage and infiltration, while the opposite conditions favor natural grasslands.

Aquino et al. (2015) and Campos et al. (2011) asserted that terrain micro-variations can promote geospatial variation of soil attributes, even when the areas seem to be homogeneous (Oliveira et al., 2015a), affecting crop yield and soil analysis accuracy, which uses sample mean of the area. Moreover, Souza et al. (2006) stated that extra statistical analyses are needed to measure such variations, because most of the soils change over time and space.

Within this context, geostatistical methods are being widely used, since they check the geographical coordinates of sample points in line with the soil properties within a geospatial domain (KAMIMURA et al., 2013; CORTEZ et al., 2011; SILVA et al., 2010) and, the occurrence of the assessed attributes enable the generation of kriging 
maps that display dynamics of soil attributes over the area, being an important aid for decision making regarding environmental and agricultural use (AQUINO et al., 2015; OLIVEIRA et al., 2013).

This research aimed to assess physical and geospatial attributes of Cambisol and Ultisol under grassland and forest areas in Humaitá County - AM, Brazil.

\section{MATERIAL AND METHODS}

The study was carried in two locations, Humaitá (Southern Amazonas State) and around border areas with Northern Rondônia State, at the geographical coordinates of $7^{\circ} 30^{\prime} 24^{\prime \prime} \mathrm{S}$ and $63^{\circ} 04^{\prime}$ $56^{\prime \prime} \mathrm{W}$, respectively. The area has two typical vegetal formations that are dense forests and natural grasslands. According to Köppen, the local climate belongs to the group A (Rainy Tropical Climate) and Am type, which stands for areas with a short dry season, a rainy season from October to June and mean annual rainfall around 2,250 and 2,750 mm. Annual mean temperatures range from 25 to $27^{\circ} \mathrm{C}$ and air relative humidity between 85 and $90 \%$.

The region is geologically formed from undifferentiated alluvium, which are chronologically derived from Holocene period and its sediments arising from two sedimentation cycles: a) inferior sandbanks, representing pluvio-fluvial sedimentation and, b) higher clayey sediments indicating lake sedimentation (CAMPOS et al., 2010).

We chose high field and forest areas to perform this study, since they are the most frequent within the region. It was built a sampling grid in the dimensions of $70 \times 70 \mathrm{~m}$ in each area, with a $10-\mathrm{m}$ regular spacing between the points, totaling 64 sampling points in each mesh. The sampling points were georeferenced with a GPSMAP 76CS (Garmin International, USA) with an accuracy $<10 \mathrm{~m}$.

Macro and microporosity, bulk density and total porosity were determined by preserved structure soil samples, which were collected with a volumetric ring at $0.0-0.05 ; 0.05-0.10$ and $0.10-0.20$ $\mathrm{m}$ depths. In the laboratory, samples were prepared by withdrawing soil excess from the ends of the rings and then saturated by gradual increase of water on a plastic tray up to reach approximately $2 / 3$ the sample height. After saturation, they were weighed and microporosity determined by the tension table method, being subjected to a $0.006 \mathrm{MPa}$ tension (EMBRAPA, 1997).

After reaching equilibrium at a matric potential of $-0.006 \mathrm{MPa}$, the samples were weighed and then was measured soil penetration resistance
(RP), using an electronic penetrometer Model MA933, trade mark Marconi, equipped with a cell load of $200 \mathrm{~N}$, with cone shaft $4 \mathrm{~mm}$ base diameter and half-angle of 30 degrees, a constant speed of penetration $0.1667 \mathrm{~mm} \mathrm{~s}-1$, and receiver interface coupled to a computer for registration of readings using a specific product software. The samples from $5 \mathrm{~mm}$ of the upper and lower samples were discarded in order to eliminate the effect of the periphery of the sample

After reaching equilibrium at a matric potential of $-0.006 \mathrm{MPa}$, the samples were weighed and then soil resistance to penetration (SRP) was measured, using an electronic penetrometer model MA-933 (Marconi Equipment, Piracicaba, SP, Brazil), with a load cell of $200 \mathrm{~N}$, rod with a 4-mm base diameter cone and $30^{\circ}$ half-angle. The equipment operated at a constant penetration speed of $0.1667 \mathrm{~mm} \mathrm{~s}^{-1}$. A receiver and an interface coupled to a computer recorded readings using a specific software. The upper and lower $5 \mathrm{~mm}$ of each sample were discarded to eliminate edge effect (BRADFORD, 1986).

After SRP determination, samples were dried in an oven at 105 to $110{ }^{\circ} \mathrm{C}$ for $48 \mathrm{~h}$ to ascertain volumetric humidity and Ds by the volumetric ring method. TP and MaP were determined according to method proposed by Embrapa (1997).

Data were submitted to descriptive analysis, through which it was determined mean, maximum and minimum values, asymmetry and Kurtosis coefficient, variation coefficient (VC) and data frequency distribution. This analysis was performed by Minitab 14 statistical software (MINITAB, 2000).

Geostatistics was used to characterize spatial variability. Experimental semivariogram was estimated by the equation (1).

$$
\hat{\gamma}(h)=\frac{1}{2 N(h)} \sum_{i=1}^{N(h)}\left[Z\left(x_{i}\right)-Z\left(x_{i}+h\right)\right]^{2}
$$

Wherein: $\gamma(\mathrm{h})$ - semivariance at an $\mathrm{h}$ distance; $\mathrm{N}(\mathrm{h})$ - number of pairs in a semivariance calculation; $\mathrm{Z}\left(\mathrm{x}_{\mathrm{i}}\right)-\mathrm{Z}$ attribute value at $\mathrm{x}_{\mathrm{i}} ; \mathrm{Z}\left(\mathrm{x}_{\mathrm{i}}+\mathrm{h}\right)-\mathrm{Z}$ attribute value at an $h$ distance from $x_{i}$.

Experimental semivariogram were chosen based on the number of pairs within the semivariance calculation of the first lags, with a clearly defined sill (BURROUGH and MCDONNEL, 2000) and the result of Jack Knifing technique (VAUCLIN et al., 1983).

After mathematical model fit, data were interpolated through kriging. $\mathrm{GS}^{+}$software 
performed geostatistical analysis and Surfer 8.00 the kriging maps.

\section{RESULTS AND DISCUSSION}

Table 1 shows the descriptive statistics of soil physical attributes for both areas. Mean and median have similar values at the different evaluated depths and areas. It reveals a normal or symmetrical data distribution. Such results corroborate with findings of Kamimura et al. (2013).

Asymmetry and Kurtosis are data distribution indicators; however, they are more sensible to extreme values than mean and median that, when near to zero indicate data normality and, as consequence, semivariogram best fit (CORTEZ et al., 2011). Thus, Table 1 shows that asymmetry and Kurtosis values of most variables are near to zero in both depths and areas.
ALHO, L. C. et al.

According to the results of KolmogorovSmirnov normality test, only the MaP at 0.05-0.10 and 0.10-0.20 m depths, SRP and TP at 0.10-0.20 m depth, in the natural grassland and $\mathrm{MaP}$ at $0.10-0.20$ $\mathrm{m}$ in the forest were significant by the test, i.e., they did not present normality.

For comparison purposes, it was adopted variation coefficient limits proposed by Warrick \& Nielsen (1980) to classify the variability of studied attributes, being: $\mathrm{VC}<12 \% ; 12 \%<\mathrm{VC}<60 \%$ and $\mathrm{VC}>60 \%$, which are considered low, medium and high, respectively. This way, Ds, MiP and TP at $0.0-0.05 ; 0.05-0.10$ and $0.10-0.20 \mathrm{~m}$ depths in both environments were low. These results are similar to those found by Lima et al. (2009), except for SRP and $\mathrm{MaP}$ in both environments and at the different depths, which presented moderate variability; and $\mathrm{MaP}$ at $0.10-0.20 \mathrm{~m}$ depth in the natural grassland has high variability.

Table 1. Descriptive statistics and geostatistics of physical attributes in soils under natural grasslands and forest in Humaitá - AM, Brazil.

\begin{tabular}{|c|c|c|c|c|c|c|c|c|c|c|}
\hline \multirow{4}{*}{$\begin{array}{l}\text { Descriptive } \\
\text { Statistics }\end{array}$} & \multicolumn{5}{|c|}{ Haplic Cambisol/natural grasslands } & \multicolumn{5}{|c|}{ Red Ultisol/forest } \\
\hline & $\mathrm{RP}$ & Ds & $\mathrm{MaP}$ & $\mathrm{MiP}$ & VTP & RP & Ds & $\mathrm{MaP}$ & $\mathrm{MiP}$ & VTP \\
\hline & $\mathrm{MPa}$ & $\mathrm{kg} \mathrm{dm}_{3}^{-}$ & & $\mathrm{m}^{3} \mathrm{~m}^{-3}$ & & $\mathrm{MPa}$ & $\mathrm{kg} \mathrm{dm}_{3}^{-}$ & & $\mathrm{m}^{3} \mathrm{~m}^{-3}$ & \\
\hline & \multicolumn{10}{|c|}{$0,0-0,05 \mathrm{~m}$} \\
\hline Mean & 1.98 & 1.37 & 0.08 & 0.36 & 0.45 & 0.77 & 1.16 & 0.14 & 0.37 & 0.51 \\
\hline Median & 1.99 & 1.37 & 0.08 & 0.37 & 0.45 & 0.76 & 1.15 & 0.14 & 0.37 & 0.50 \\
\hline Maximum & 2.73 & 1.51 & 0.16 & 0.41 & 0.51 & 1.25 & 1.32 & 0.20 & 0.41 & 0.57 \\
\hline Minimum & 1.12 & 1.21 & 0.02 & 0.31 & 0.38 & 0.40 & 1.00 & 0.10 & 0.33 & 0.44 \\
\hline${ }^{1} \mathrm{CV}(\%)$ & 20.65 & 5.64 & 45.69 & 6.36 & 7.13 & 27.59 & 6.10 & 16.22 & 5.09 & 5.15 \\
\hline Asymmetry & -0.27 & -0.10 & 0.25 & -0.11 & -0.06 & 0.26 & 0.07 & 0.48 & 0.15 & 0.11 \\
\hline Kurtosis & -0.59 & -0.86 & -0.87 & -0.55 & -0.56 & -0.53 & -0.08 & -0.16 & -0.30 & -0.04 \\
\hline \multirow[t]{2}{*}{${ }^{2} \mathrm{~d}$} & $0.08^{\mathrm{ns}}$ & $0.05^{\mathrm{ns}}$ & $0.05^{\mathrm{ns}}$ & $0.05^{\mathrm{ns}}$ & $0.04^{\mathrm{ns}}$ & $0.05^{\mathrm{ns}}$ & $0.05^{\mathrm{ns}}$ & $0.05^{\mathrm{ns}}$ & $0.04^{\mathrm{ns}}$ & $0.08^{\mathrm{ns}}$ \\
\hline & \multicolumn{10}{|c|}{$0,05-0,10 \mathrm{~m}$} \\
\hline Mean & 2.07 & 1.49 & 0.06 & 0.35 & 0.41 & 0.77 & 1.20 & 0.14 & 0.37 & 0.51 \\
\hline Median & 2.14 & 1.50 & 0.05 & 0.35 & 0.41 & 0.79 & 1.21 & 0.14 & 0.37 & 0.51 \\
\hline Maximum & 2.61 & 1.63 & 0.14 & 0.40 & 0.48 & 1.32 & 1.34 & 0.22 & 0.40 & 0.56 \\
\hline Minimum & 1.28 & 1.28 & 0.02 & 0.29 & 0.37 & 0.30 & 0.89 & 0.10 & 0.30 & 0.42 \\
\hline${ }^{1} \mathrm{CV}(\%)$ & 16.75 & 5.07 & 49.41 & 6.55 & 6.68 & 28.55 & 7.79 & 20.57 & 5.29 & 5.07 \\
\hline Asymmetry & -0.50 & -0.21 & 1.12 & -0.12 & 0.43 & 0.16 & -1.09 & 0.63 & -0.61 & -0.44 \\
\hline Kurtosis & -0.49 & -0.30 & 1.03 & 0.04 & -0.20 & 0.07 & 1.38 & -0.29 & 1.08 & 0.98 \\
\hline \multirow[t]{2}{*}{${ }^{2} \mathrm{~d}$} & $0.08^{\mathrm{ns}}$ & $0.07^{\mathrm{ns}}$ & $0.12 *$ & $0.02^{\mathrm{ns}}$ & $0.06^{\mathrm{ns}}$ & $0.08^{\mathrm{ns}}$ & $0.09^{\mathrm{ns}}$ & $0.07^{\mathrm{ns}}$ & $0.03^{\mathrm{ns}}$ & $0.04^{\mathrm{ns}}$ \\
\hline & \multicolumn{10}{|c|}{$0,10-0,20 \mathrm{~m}$} \\
\hline Mean & 2.08 & 1.54 & 0.05 & 0.24 & 0.29 & 0.85 & 1.26 & 0.13 & 0.37 & 0.50 \\
\hline Median & 2.02 & 1.54 & 0.04 & 0.24 & 0.28 & 0.86 & 1.27 & 0.14 & 0.37 & 0.50 \\
\hline Maximum & 3.36 & 1.72 & 0.14 & 0.27 & 0.38 & 1.42 & 1.44 & 0.22 & 0.40 & 0.57 \\
\hline Minimum & 1.26 & 1.35 & 0.01 & 0.22 & 0.24 & 0.25 & 0.99 & 0.08 & 0.33 & 0.45 \\
\hline${ }^{1} \mathrm{CV}(\%)$ & 22.69 & 5.88 & 65.40 & 5.69 & 11.87 & 33.57 & 7.79 & 21.87 & 4.14 & 5.12 \\
\hline Asymmetry & 0.86 & -0.21 & 0.99 & 0.26 & 1.01 & 0.08 & -0.46 & 1.08 & -0.23 & 0.61 \\
\hline Kurtosis & 0.55 & -0.61 & 0.15 & -0.98 & 0.52 & -0.74 & 0.30 & 1.30 & -0.37 & 0.30 \\
\hline${ }^{2} \mathrm{~d}$ & $0.11 *$ & $0.06^{\mathrm{ns}}$ & $0.14 *$ & $0.06^{\mathrm{ns}}$ & $0.12 *$ & $0.07^{\mathrm{ns}}$ & $0.05^{\mathrm{ns}}$ & $0.10 *$ & $0.04^{\mathrm{ns}}$ & $0.05^{\mathrm{ns}}$ \\
\hline
\end{tabular}

SRP: soil resistance to penetration; Ds: soil bulk density; MaP: macroporosity; MiP: microporosity; TP: total porosity; ${ }^{\mathrm{I}} \mathrm{VC}$ : variation coefficient; ${ }^{2} \mathrm{~d}$ : Kolmogorov-Smirnov normality test; *significant at $5 \%$ probability. 
Table 2 introduces the geostatistical parameters. Exponential and spherical were the semivariogram models that best fitted soil physical attributes in grasslands and forest, respectively. Nevertheless, for some attributes as T and Ds at 0.0$0.05 \mathrm{~m}$ and $0.05-0.10 \mathrm{~m}$ depths, respectively, regarding forest and natural grasslands, a pure nugget effect (PNE) was encountered, that is, there was no spatial dependence for the studies sampling distance (OLIVEIRA et al., 2015 a). PNE points out for non-explained or non-detected variability, which may occur due to measurement or sampling errors, or even attribute micro-variations (CAMBARDELLA et al., 1994).

Several results indicate exponential and spherical models are the ones best fitted for soil physical attributes (AQUINO et al., 2015; MENDES et al., 2006). However, it is noteworthy to mention that the models were adjusted through determination coefficient $\left(\mathrm{R}^{2}\right)$, which were above 0.75 ; and cross-validation $(\mathrm{CV})$ values were on average for both areas superior to 0.65 , which means that these models are the most representative, corroborating to Chig et al. (2008) and Silva et al. (2010).

Table 2. Geostatistics of physical attribute of soil under natural grassland and forest in Humaitá - AM, Brazil.

\begin{tabular}{|c|c|c|c|c|c|c|c|c|c|c|}
\hline \multirow{4}{*}{ Geostatistics } & \multicolumn{5}{|c|}{ Haplic Cambisol/natural grasslands } & \multicolumn{5}{|c|}{ Red Ultisol/forest } \\
\hline & RP & Ds & $\mathrm{MaP}$ & $\mathrm{MiP}$ & VTP & $\mathrm{RP}$ & Ds & $\mathrm{MaP}$ & $\mathrm{MiP}$ & VTP \\
\hline & $\mathrm{MPa}$ & $\mathrm{kg} \mathrm{dm}^{-3}$ & & $\mathrm{~m}^{3} \mathrm{~m}^{-3}$ & & $\mathrm{MPa}$ & $\mathrm{kg} \mathrm{dm}^{-3}$ & & $\mathrm{n}^{3} \mathrm{~m}^{-3}$ & \\
\hline & \multicolumn{10}{|c|}{$0,0-0,05 \mathrm{~m}$} \\
\hline Model & Exp. & Exp. & Exp. & Esf. & Exp. & Exp. & Esf. & Esf. & Exp. & Lin. \\
\hline Reach (m) & 24.0 & 22.0 & 26.0 & 21.0 & 22.0 & 43.0 & 30.0 & 51.0 & 33.0 & - \\
\hline${ }^{1} \mathrm{R}^{2}$ & 0.75 & 0.86 & 0.89 & 0.85 & 0.87 & 0.95 & 0.96 & 0.97 & 0.92 & - \\
\hline${ }^{2} \mathrm{GDE}(\%)$ & 11.3 & 14.0 & 13.0 & 17.0 & 13.6 & 18.0 & 31.8 & 45.3 & 11.6 & EPP \\
\hline \multirow[t]{2}{*}{${ }^{3} \mathrm{VC}$} & 0.79 & 0.60 & 0.60 & 0.87 & 0.63 & 0.78 & 0.68 & 0.82 & 0.74 & - \\
\hline & \multicolumn{10}{|c|}{$0,05-0,10 \mathrm{~m}$} \\
\hline Model & Exp. & Lin. & Exp. & Exp. & Exp. & Esf. & Exp. & Exp. & Exp. & Esf. \\
\hline Reach (m) & 20.0 & - & 36.0 & 34.0 & 23.0 & 36.0 & 43.0 & 22.0 & 22.0 & 26.0 \\
\hline${ }^{1} \mathrm{R}^{2}$ & 0.75 & - & 0.95 & 0.88 & 0.66 & 0.85 & 0.99 & 0.92 & 0.87 & 0.90 \\
\hline${ }^{2} \mathrm{GDE}(\%)$ & 12.0 & EPP & 9.2 & 15.9 & 14.3 & 40.4 & 15.0 & 12.7 & 10.2 & 12.0 \\
\hline \multirow[t]{2}{*}{${ }^{3} \mathrm{VC}$} & 0.79 & - & 0.67 & 0.60 & 0.78 & 0.77 & 0.55 & 0.61 & 0.80 & 0.86 \\
\hline & \multicolumn{10}{|c|}{$0,10-0,20 \mathrm{~m}$} \\
\hline Model & Esf. & Exp. & Exp. & Exp. & Exp. & Exp. & Esf. & Esf. & Exp. & Esf. \\
\hline Reach (m) & 33.0 & 41.0 & 34.0 & 25.0 & 29.0 & 36.0 & 34.0 & 38.0 & 33.0 & 26.0 \\
\hline${ }^{1} \mathrm{R}^{2}$ & 0.85 & 0.93 & 0.91 & 0.88 & 0.86 & 0.93 & 0.98 & 0.97 & 0.89 & 0.86 \\
\hline${ }^{2} \mathrm{GDE}(\%)$ & 14.6 & 14.7 & 13.3 & 10.0 & 12.5 & 17.0 & 37.6 & 32.8 & 14.2 & 23.0 \\
\hline${ }^{3} \mathrm{VC}$ & 0.76 & 0.86 & 0.72 & 0.76 & 0.77 & 0.60 & 0.84 & 0.58 & 0.65 & 0.53 \\
\hline
\end{tabular}

SRP: soil resistance to penetration; Ds: soil density; MaP: macroporosity; MiP: microporosity; TP: total porosity; Sph. spherical; Exp.: exponential; Lin: linear; ${ }^{1} \mathrm{R}^{2}$ : correlation coefficient; ${ }^{2} \mathrm{SDD}$ : spatial dependence degree; ${ }^{3} \mathrm{CV}$ : cross-validation.

Spatial dependence degree (SDD) of the variables was assessed according to Cambardella et al. (1994), in which: SDD values smaller than $25 \%$, indicate strong spatial dependence; values between 25 and $75 \%$ show moderate dependence; and values higher than $75 \%$, point weak dependence. It was assigned to the variables in natural grasslands and forest areas at the varied depths, a strong spatial dependence, except for Ds, MaP and SRP that had moderate classification at some depths (Table 2).

Semivariance stabilization occurs at a certain distance, which is referred to as spatial dependence range (a). It can be interpreted as the distance over which the values of the variables under study do not correlate. It varied from 21 to 26 $\mathrm{m} ; 20$ to $36 \mathrm{~m}$ and 25 to $41 \mathrm{~m}$, at respective depths of $0.0-0.05 ; 0.05-0.10$ and $0.10-0.20 \mathrm{~m}$ in natural grasslands.
In forest area, range varied from 30 to $51 \mathrm{~m}$; 22 to $36 \mathrm{~m}$ and 26 to $38 \mathrm{~m}$, at $0.0-0.05 ; 0.05-0.10$ and $0.10-0.20 \mathrm{~m}$ depths, respectively. Oliveira et al. (2013) claimed that range value influences estimate quality, and this is what determines the number of values used in the interpolation. It must be highlighted that estimates obtained via ordinary kriging interpolation, using higher range values are more reliable, with maps that best represent the reality.

As for the physical characteristics of the soil properties, it was observed in the natural grasslands Ds values of $1.37,1.49$ and $1.54 \mathrm{~kg} \mathrm{dm}^{-3}$ at the different depths (Table 1). Arshad et al. (1996) stated that Ds values superior to $1.40 \mathrm{~kg} \mathrm{dm}^{-3}$ for medium texture and clayey soils may cause restrictions on root growth. Several authors had stated that Ds is an attribute that varies with time by 
natural densification processes and management practices, decreasing soil porosity, especially macroporosity (ARAÚJO et al., 2007; CARDOSO et al., 2011).

Campos et al. (2012a) observed that Inceptisols, in natural grasslands, have a texture ranging from medium to silt-loam and grade grains in sub-angular blocks at a depth of 0.0 to $0.30 \mathrm{~m}$. According to Castione et al. (2015) and Oliveira et al. (2015b), soil can become dense as a result of its textural composition, moisture regime and genesis; pointing out that at subsurface layers, it can be due to packaging of granular sediments, partially cemented, in which soils with structures in blocks or similar tend to be denser. In the present study, these characteristics delineate the likely cause of high Ds in the grasslands.

In the forest area, Ds mean value varied from 1.16 to $1.26 \mathrm{~kg} \mathrm{dm}^{-3}$ at $0.0-0.05$ and $0.10-0.20$ $\mathrm{m}$ depths, respectively. Considering different types of vegetation, but with a very similar texture, it is believed that lower Ds in forest area is related to littering accumulation, as reported by Martins et al. (2006).

SRP had correlation with Ds, that is, while in the forest the SRP mean value was $0.85 \mathrm{MPa}$ at 0.10-0.20 m, and 0.77 MPa for both depths; SRP values in the grasslands were higher than $2.00 \mathrm{MPa}$ (Table 1). Similar results are described by Abreu et al. (2003) and Campos et al. (2012b) in Ultisols and Inceptisols, respectively. According to Tormena and
ALHO, L. C. et al.

Rollof (1996), SRP values equal or above $2.00 \mathrm{MPa}$ are critical and can restrict root growth.

Concerning $\mathrm{MaP}$, mean values in the grasslands at all depths were higher than $0.08 \mathrm{~m}^{3} \mathrm{~m}^{-}$ 3. Assis and Lanças (2005) ascertained that MaP values smaller than $0.10 \mathrm{~m}^{3} \mathrm{~m}^{-3}$ denote inadequate aeration to meet the needs of root system and soil microorganisms. Additionally, as a result, according to Araujo et al. (2007), it reflects in a lower soil infiltration rate, and therefore favors erosion by runoff, sedimentation and pollution of water reservoirs, resulting from sediment deposition carried by floods from agricultural sector activities.

In the natural grasslands, $\mathrm{MiP}$ average value was $0.36 \mathrm{~m}^{3} \mathrm{~m}^{-3}$ at superficial layers, being similar to those found in the forest; however, there was a reduction to $0.24 \mathrm{~m}^{3} \mathrm{~m}^{-3}$ at the $0.10-0.20 \mathrm{~m}$ layer. On the other hand, in the forest, invariable values of $\mathrm{MaP}$ and MiP were 0.14 and $0.37 \mathrm{~m}^{3} \mathrm{~m}^{-}$, respectively; and associated with SRP and Ds values characterize soil physical stability for that environment (MARTINS et al., 2006; CAMPOS et al., 2012a).

As presented in Figure 1 and 2, geospatial distribution of soil attributes was assessed by kriging maps. The maps of natural grasslands show a greater heterogeneity of attribute distribution, as the scale of values defined in this study (Figure 1). It is justified by a lower range of spatial dependence (Table 2) and relief micro-variations (CAMPOS et al., 2011).

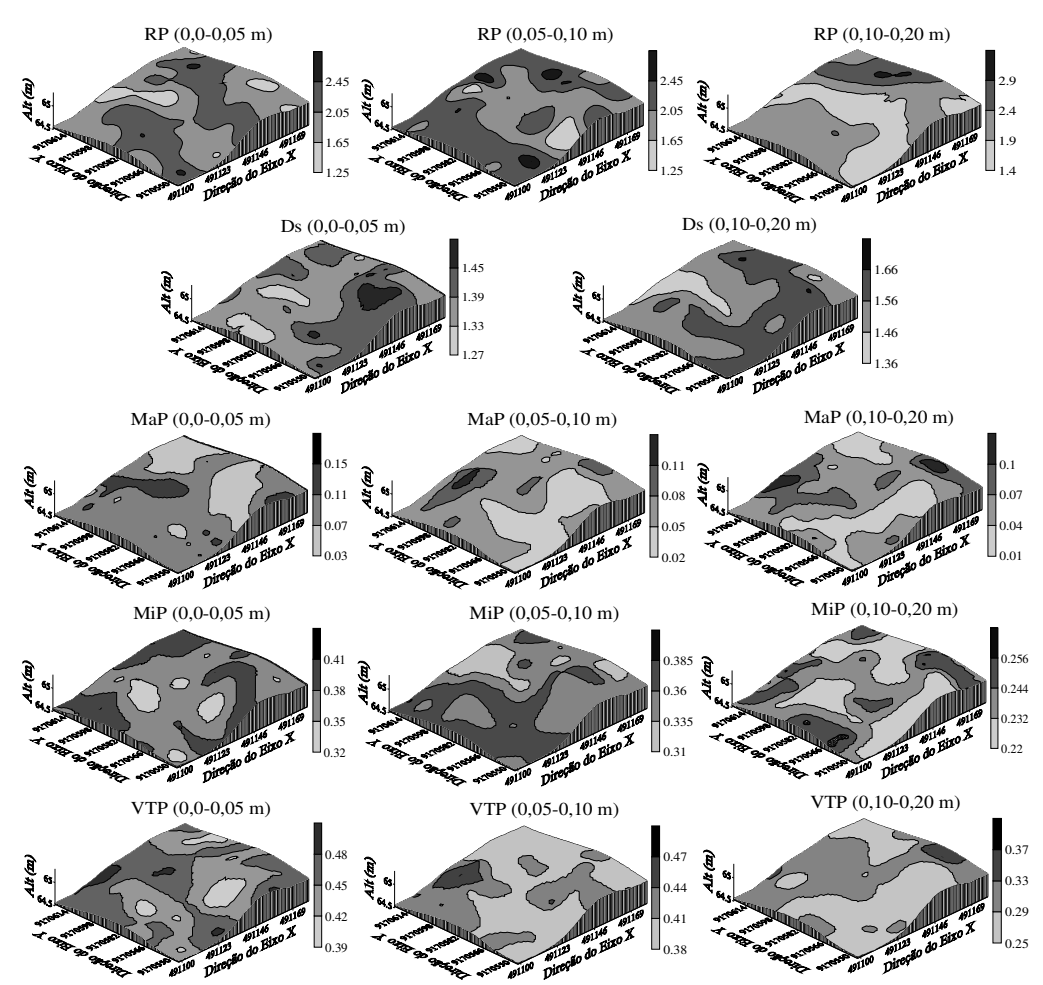

Figure 1. Kriging maps of soil physical attributes in natural grasslands at different depths. 
Linear relief format in the forest, albeit with little slope facing the land central part, promoted greater continuity of soil attributes, what is confirmed by a greater range of spatial dependence (Table 2, Figure 2), which corroborates with Campos et al. (2013), who found greater spatial continuity of attributes in a forest area in the district of Manicoré-AM, Brazil. It was observed that greater values of SRP and Ds are correlated and inversely proportional to $\mathrm{MaP}$ in the same region (Figure 2).

The lowest MiP volume at $0.10-0.20 \mathrm{~m}$ depth compared to superficial layers, as well as MaP, irrespectively the evaluated layer, implies in TP reduction. These characteristics added up to the expressive values of Ds and SRP reveal inefficiency of structural functions in the natural grasslands, which distinguishes soil physical quality.

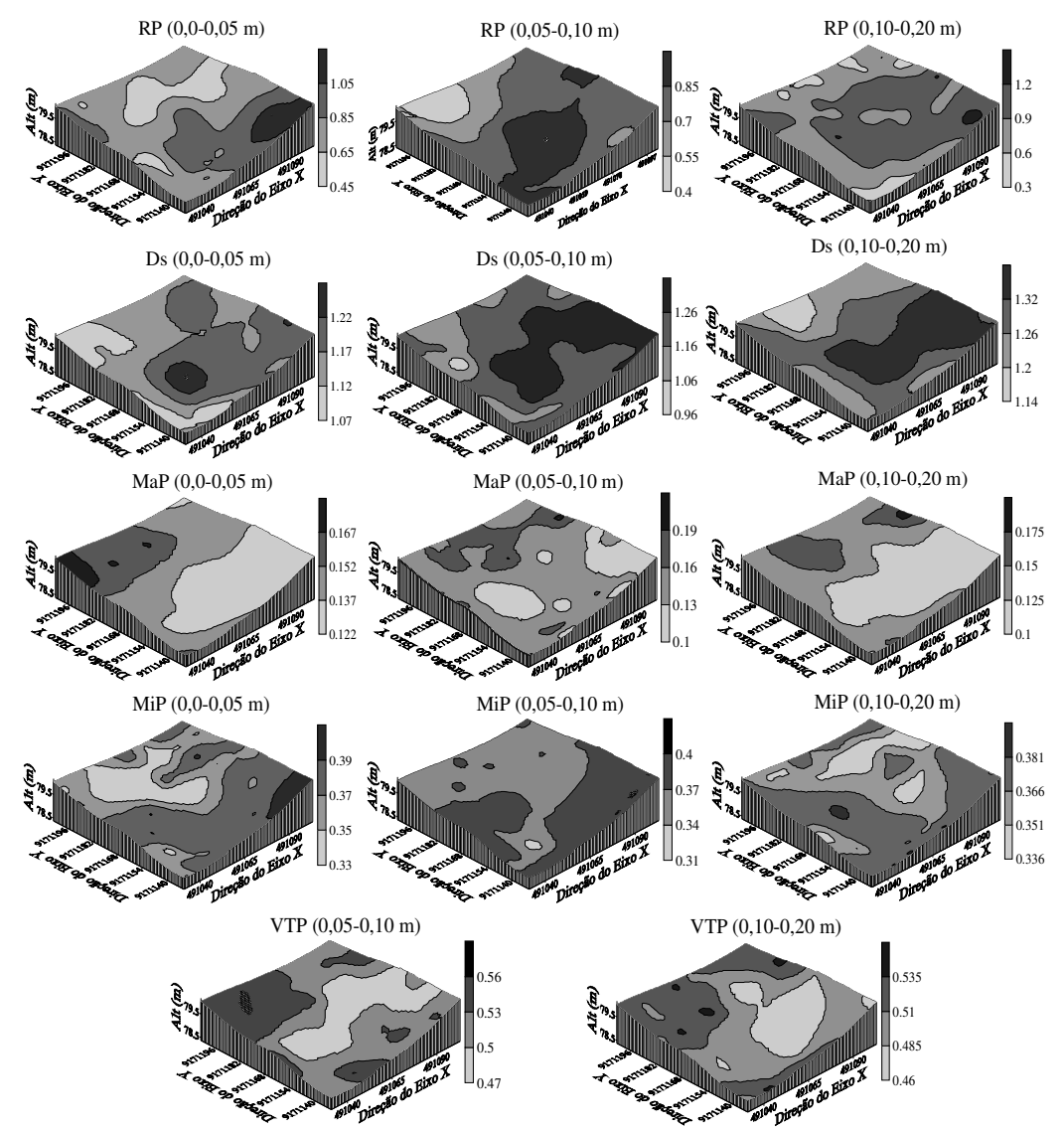

Figure 2. Kriging maps of soil physical attributes in forest at different depths.

\section{CONCLUSIONS}

Kriging maps of natural grassland area indicate that a lower continuity of the spatial dependence structure of soil attributes comes from constant relief micro-variations on this area.

Forest Ultisols showed greater values of range and, consequently, higher geospatial continuity of the physical attributes, which is related to the improved stability of this soil physical structure.

Pedogenic processes and grain size morphological characteristics in Inceptisols constitute the main factors of soil densification in natural grasslands.

Based on physical characteristics, the inefficiency of structural functions in Inceptisols is the determining factor for grassland vegetation occurrence in this region.

\section{ACKNOWLEDGEMENTS}

The authors would like to thank the FAPEAM and SECTI-AM for financial support.

RESUMO: Na porção sul e leste do Amazonas, oeste de Rondônia e norte de Roraima há ocorrência de campos naturais com características savânicas associadas a mosaicos florestais, condicionadas aos fatores edáficos locais. $\mathrm{O}$ 
objetivo deste estudo foi avaliar os atributos físicos e geoespaciais de um Cambissolo sob campos naturais e Argissolo sob fragmento florestal em Humaitá, AM. Em cada área foi estabelecida uma malha amostral nas dimensões de $70 \times 70 \mathrm{~m}$, com espaçamentos regulares de amostragem de $10 \mathrm{~m}$ e três profundidades de coleta: 0,0-0,05; 0,05-0,10 e 0,10-0,20 m, totalizando 192 pontos de coleta. Para as determinações da macroporosidade (MaP), microporosidade (MiP), densidade do solo (Ds) e volume total de poros (VTP) foram coletadas amostras com estrutura preservada, utilizando-se anéis volumétricos. Após serem submetidos a uma tensão de 0,006 MPa, as mesmas amostras foram utilizadas para medir a resistência do solo à penetração (RP), utilizando um penetrógrafo eletrônico. Os resultados foram submetidos às análises estatística descritiva e geoestatística. O solo sob campo natural apresentou valores considerados críticos de Ds, RP, MaP em todas as profundidades avaliadas, obtendo-se valores mais expressivos na profundidade de $0,10-0,20 \mathrm{~m}$, da ordem de $1,54 \mathrm{~kg} \mathrm{dm}^{-3} ; 2,08 \mathrm{MPa}$; e $0,05 \mathrm{~m}^{3} \mathrm{~m}^{-3}$, respectivamente. O Argissolo do fragmento florestal apresentou maiores alcances e consequente maior continuidade geoespacial correlativa aos atributos físicos avaliados, mediante a maior estabilidade da estrutura física desse solo. Com base nas características físicas do solo, a ineficiência das funções estruturais do Cambissolo é o fator determinante da ocorrência de vegetação campestre nessa região.

PALAVRAS-CHAVE: Atributos do solo. Campo natural. Floresta.

\section{REFERENCES}

ABREU, S. L.; REICHERT, J. M.; DALVAN, V. R. S.; REINERT, J.; BLUME, E. Variabilidade espacial de propriedades físico-hídricas do solo, da produtividade e da qualidade de grãos de trigo em Argissolo francoarenoso sob plantio direto. Ciência Rural, Santa Maria, v. 33, n. 2, p. 275-282, 2003.

http://dx.doi.org/10.1590/S0103-84782003000200015

AQUINO, R. E.; CAMPOS, M. C. C.; MARQUES JUNIOR, J.; OLIVEIRA, I. A.; TEIXEIRA, D. B.; CUNHA, J. M. Use of scaled semivariograms in the planning sample of soil physical properties in Southern Amazonas, Brazil. Revista Brasileira de Ciência do Solo, Viçosa, v. 39, n. 1, p. 21-30, 2015.

ARAÚJO, R.; GOEDERT, W. J. ; LACERDA, M. P. C. Qualidade de um solo sob diferentes usos e sob cerrado nativo. Revista Brasileira de Ciência do Solo, Viçosa, v. 31, n. 2, p. 1099-1108, 2007.

ARSHAD, M. A.; LOWERY, B.; GROSSMAN, B. Physical tests for monitoring soil quality. In: DORAN, J. W.; JONES, A. J., eds. Methods for assessing soil quality. Madison, Soil Science Society of America, Madison 1996. p. 123-141.

ASSIS, R. L.; LANÇAS, K. P. Avaliação dos atributos físicos de um Nitossolo Vermelho distroférrico sob sistema plantio direto, preparo convencional e mata nativa. Revista Brasileira de Ciência do Solo, Viçosa, v. 29, n. 3, p. 515-522, 2005.

BRADFORD, J. M. Penetrability. In: KRUTE, A., ed. Methods of soil analysis. 2. ed. Madison, American Society of Agronomy, Madison, 1986. P. 463-478.

BURROUGH, P. A.; McDONNEL, R. A. Principles of geographical information systems. Oxford, Oxford University Press, 2000.

CAMBARDELLA, C. A.; MOORMAN, T. B.; NOVAK, J. M.; PARKIN, T. B.; KARLEN, D. L.; TURCO, R. F.; KONOPKA, A. E. Field-scale variability of soil properties in Central Iowa. Soil Science Society American Journal, Madison, v. 58, n. 6, p. 1501-1511, 1994. http://dx.doi.org/10.2136/sssaj1994.03615995005800050033x

CAMPOS, M. C. C.; OLIVEIRA, I. A.; SANTOS, L. A. C.; AQUINO, R. E.; SOARES, M. D. R. Variabilidade espacial da resistência do solo à penetração e umidade em áreas cultivadas com mandioca na região de Humaitá, AM. Agro@mbiente On-line, Boa Vista, v. 6, n. 2, p. 09-16, 2012 b. 
CAMPOS, M. C. C.; RIBEIRO, M. R.; SOUZA JÚNIOR, V. S.; RIBEIRO FILHO, M. R.; SOUZA, R. V. C. C.; ALMEIDA, M. C. Topossequência de solos na transição Campos Naturais-Floresta na região de Humaitá, Amazonas. Acta Amazônica, Manaus, v. 42, n. 3, p. 387-398, 2012a. http://dx.doi.org/10.1590/S004459672012000300011

CAMPOS, M. C. C.; RIBEIRO, M. R,; SOUZA JÚNIOR, V. S.; RIBEIRO FILHO, M. R.; OLIVEIRA, I. A. Interferências dos pedoambientes nos atributos do solo em uma topossequência de transição Campos/Floresta. Revista Ciência Agronômica, Fortaleza, p. 41, n. 3, p. 527-535, 2010.

CAMPOS, M. C. C.; RIBEIRO, M. R.; SOUZA JÚNIOR, V. S.; RIBEIRO FILHO, M. R.; SOUZA, R. V. C. C. Relações solo-paisagem em uma topossequência sobre substrato granítico em Santo Antônio do Matupi, Manicoré (AM). Revista Brasileira de Ciência do Solo, Viçosa, v. 35, n. 4, p. 13-23, 2011.

CAMPOS, M. C. C.; SOARES, M. D. R.; SANTOS, L. A. C.; OLIVEIRA, I. A.; AQUINO, R. E.; BERGAMIN, A. C. Variabilidade espacial dos atributos físicos em um Argissolo Vermelho sob floresta. Comunicata Scientiae, Bom Jesus, v. 4, n. 3, p. 168-178, 2013.

CARDOSO, E. L.; SILVA, M. L. N.; CURI, N.; FERREIRA, M. M.; FREITAS, D. A. F. Qualidade química e física do solo sob vegetação arbórea nativa e pastagens no pantanal sul-mato-grossense. Revista Brasileira de Ciência do Solo, Viçosa, v. 35, n. 4, p. 613-622, 2011.

CASTIONI, G. F.; SOUZA, Z. M.; SILVA, R. B.; CAMPOS, M. C. C. Variabilidade de atributos físicos e crescimento de raízes do feijoeiro sob irrigação por pivô central. Revista de Ciências Agrárias, Belém, v. 58, n. 2, p. 58-68, 2015. http://dx.doi.org/10.4322/rca.1550

CHIG, L. A.; COUTO, E. G.; NOVAES FILHO, J. P.; RODRIGUES, L. C. M.; JOHNSON, M. S.; WEBER, O. L. S. Distribuição espacial da granulometria, cor e carbono orgânico do solo ao longo de um transecto em microbacias na Amazônia meridional. Acta Amazônica, Manaus, v. 38, n. 3, p. 715-722, 2008. http://dx.doi.org/10.1590/S0044-59672008000400015

CORTEZ, J. W.; ALVES, A. D. S.; MOURA, M. R. D.; OLSZEVSKI, N.; NAGAHAMA, H. J. Atributos físicos do Argissolo Amarelo do semiárido nordestino sob sistemas de preparo. Revista Brasileira de Ciência do Solo, Viçosa, v. 35, n. 3, p. 1207-1216, 2011.

EMPRESA BRASILEIRA DE PESQUISA AGROPECUÁRIA - EMBRAPA. Centro Nacional de Pesquisa de Solos. Manual de métodos de análise de solo. Rio de Janeiro, 1997. 212p.

FREITAS, H. A.; PESSENDA, L. C. R.; ARAVENA, R., GOUVEIA, S. E. M.; RIBEIRO, A. S.; BOULET, R. Floresta $\times$ Savana no passado da Amazônia. Ciência Hoje, São Paulo, v. 32, n. 2, p. 40-46, 2006.

KAMIMURA, K. M.; SANTOS, G. R.; OLIVEIRA, M. S.; DIAS JUNIOR, M. SOUZA.; GUIMARÃES, P. T. G. Variabilidade espacial de atributos físicos de um Latossolo Vermelho-Amarelo, sob lavoura cafeeira.

Revista Brasileira de Ciência do Solo, Viçosa, v. 37, n. 2, p. 877-88, 2013.

LIMA, J. S. S.; SATTLER, M. A.; XAVIER, A. C.; OLIVEIRA, R. B.; PASSOS, R. R.; OLIVEIRA, P. C. Variabilidade espacial da textura de um Argissolo Vermelho-Amarelo sob cultivo de pastagem e vegetação nativa. Ciência Rural, Santa Maria, v. 39, n. 2, p. 2634-2637, 2009. http://dx.doi.org/10.1590/S010384782009000900040

MARTINS, G. C.; FERREIRA, M. M.; CURI, N.; VITORINO, A. C. T.; SILVA, M. L. N. Campos nativos e matas adjacentes da região de Humaitá (AM): atributos diferenciais dos solos. Ciência e Agrotecnologia, Lavras, v. 30, n. 3, p. 221-227, 2006.

MENDES, F. G.; MELLONI, E. G. P.; MELLONI, R. Aplicação de atributos físicos do solo no estudo da qualidade de áreas impactadas, em Itajubá/MG. Cerne, v. 12, p. 211-220, 2006. 
MINITAB Release 14.1, Statistical Software. US/Canada. 2000.

OLIVEIRA, I. A.; CAMPOS, M. C. C.; AQUINO, R. E.; FREITAS, L.; SILVA, D. M. P. Spatial dependence of the aggregate stability and organic matter in a Cambisol under sugar cane cultivation. Revista Caatinga, Mossoró, v. 26, n. 4, p. 1-16, 2013.

OLIVEIRA, I. A.; CAMPOS, M. C. C.; FREITAS, L.; SOARES, M.D.R. Caracterização de solos sob diferentes usos na região sul do Amazonas. Acta Amazônica, Manaus, v. 45, n. 1, p. 1-12, 2015 b. http://dx.doi.org/10.1590/1809-4392201400555

OLIVEIRA, I. A.; CAMPOS, M. C. C.; MARQUES JUNIOR, J.; AQUINO, R. E.; TEIXEIRA, D. B.; SILVA, D. M. P. Use of scaled semivariograms in the planning sample of soil chemical properties in Southern Amazonas, Brazil. Revista Brasileira de Ciência do Solo, Viçosa, v. 39, n. 4, p. 31-39, 2015 a.

SILVA, J. J. N.; MONTENEGRO, A. A. A.; SILVA, Ê. F. F.; FONTES JÚNIOR, R. V. P.; SILVA, A. P. N. Variabilidade espacial de parâmetros de crescimento da mamoneira e de atributos físico-químicos em Neossolo. Revista Brasileira de Engenharia Agrícola e Ambiental, Campina Grande, v. 14, n. 4, p. 921-931, 2010. http://dx.doi.org/10.1590/S1415-43662010000900003

SOUZA, Z. M.; MARQUES JÚNIOR, J.; PEREIRA, G. T.; MONTANARI, R.; CAMPOS, M. C. C. Amostragem de atributos químicos e físicos em área com variação nas formas do relevo. Científica, Jaboticabal, v. 34, n. 3, p. 249-256, 2006.

TORMENA, C. A.; ROLLOF, G. Dinâmica da resistência à penetração de um solo sob plantio direto. Revista Brasileira de Ciência do Solo, Viçosa, v. 20, n. 4, p. 333-339, 1996.

VAUCLIN, M.; VIEIRA, S. R.; VACHAUD, G.; NIELSEN, D. R., The use of cokriging with limited field soil observations. Soil Science Society American Journal, Madison, v. 47, n. 3, p. 175-184. 1983. http://dx.doi.org/10.2136/sssaj1983.03615995004700020001x

WARRICK, A. W.; NIELSEN, D. R. Spatial variability of soil physical properties in the field. In: HILLEL, D., ed. Applications of soil physics. New York, Academic Press, 1980. p. 319-344.

http://dx.doi.org/10.1016/b978-0-12-348580-9.50018-3 